\title{
WHERE THE PICNIC WAS
}

WHERE we made the fire

In the summer time

Of branch and briar

On the hill to the sea, I slowly climb

Through winter mire, And scan and trace The forsaken place Quite readily.

Now a cold wind blows, And the grass is gray, But the spot still shows As a burnt circle - aye, And stick-ends, charred, Still strew the sward Whereon I stand, Last relic of the band Who came that day!

Yes, I am here Just as last year, And the sea breathes brine From its strange straight line Up hither, the same As when we four came.

- But two have wandered far From this grassy rise

Into urban roar

Where no picnics are, And one - has shut her eyes For evermore. 